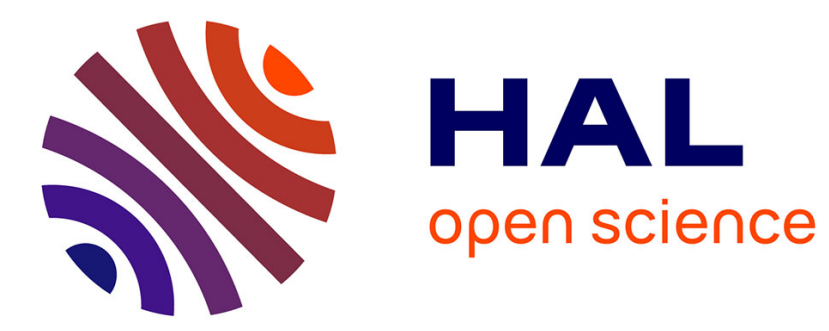

\title{
Volatile Constituents of Cucumis sativus: Differences Between Five Tropical Cultivars
}

Toulassi Atiama-Nurbel, Serge Quilici, Emilie Boyer, Jean-Philippe Deguine, Serge Glenac, Anne Gauvin-Bialecki

\section{- To cite this version:}

Toulassi Atiama-Nurbel, Serge Quilici, Emilie Boyer, Jean-Philippe Deguine, Serge Glenac, et al.. Volatile Constituents of Cucumis sativus: Differences Between Five Tropical Cultivars. Chemistry of Natural Compounds, 2015, 51 (4), pp.771-775. 10.1007/s10600-015-1408-3 . hal-01187691

\section{HAL Id: hal-01187691 \\ https://hal.univ-reunion.fr/hal-01187691}

Submitted on 16 Nov 2016

HAL is a multi-disciplinary open access archive for the deposit and dissemination of scientific research documents, whether they are published or not. The documents may come from teaching and research institutions in France or abroad, or from public or private research centers.
L'archive ouverte pluridisciplinaire HAL, est destinée au dépôt et à la diffusion de documents scientifiques de niveau recherche, publiés ou non, émanant des établissements d'enseignement et de recherche français ou étrangers, des laboratoires publics ou privés. 


\title{
VOLATILE CONSTITUENTS OF Cucumis sativus: DIFFERENCES BETWEEN FIVE TROPICAL CULTIVARS
}

\author{
T. Atiama-Nurbel, ${ }^{1}$ S. Quilici, ${ }^{1}$ E. Boyer, ${ }^{2}$ J.-P. Deguine, ${ }^{1}$ S. \\ Glenac, ${ }^{1}$ and A. Bialecki ${ }^{2}$ *
}

Cucumis sativus L. (cucumber), a creeping plant of the Cucurbitaceae family, is widely cultivated for its fruit. It is a tender annual with a rough, succulent, trailing stem and hairy leaves with three to five pointed lobes; the stem bears branched tendrils by which the plant can be trained on supports. Depending on the cultivar, the fruits are available in many different sizes, shapes, and colors. They range from thick, stubby little fruits (10-12 cm long) to Dutch greenhouse varieties (of up to $50 \mathrm{~cm}$ long). There are literally hundreds of different cultivars of C. sativus, virtually all of which can be divided into two basic types: slicing (fresh consumption) and pickling (fermented or fresh consumption). Flavor impact compounds responsible for fresh cucumber flavor are formed within seconds by enzymatic reactions that begin when tissue is disrupted [1]. Isolation and identification of volatile components from blended cucumber tissue has shown that (E,Z)-nona-2,6-dienal and (E)-non-2-enal are the major components present. Most of the studies on flavor of cucumber have been done on blended cucumbers and are limited to the identification of aldehydes $[2,3]$. In this paper, we propose to characterize the whole volatile emission of pieces of cucumbers of five different tropical cultivars using SPME collection and gas chromatography/mass spectrometry (GC/MS) detection. Four slicing cultivars ("Showy Green," "Tropical," "F1 L-04," "Pointe Blanche") and one pickling cultivar ("Antilla") of cucumber were studied (Table 1) according to their good adaptability to tropical conditions. Several studies had shown that the solid-phase microextraction (SPME) technique for collecting volatiles of blended fruit $[2,4,5]$ and slices of fruit [6] provided information comparable with that obtained with other extraction techniques, but was more convenient and faster to perform [7].

Forty-eight compounds were identified, which accounted for 88.4, 93.8, 97.8, 98.3, and $93.6 \%$ of the total composition, respectively, for "Showy Green," "Tropical," "F1 L-04," "Pointe Blanche," and "Antilla" cultivars. The identified components were classified in Table 2 into eleven groups according to their elution order on the SPB-5 column within each group: alkanes, alkenes, alcohols, aldehydes, esters, ethers, monoterpenes (either hydrocarbons or oxygenated derivatives), sesquiterpenes (either hydrocarbons or oxygenated derivatives), and miscellaneous components. The principal compounds (>10\%) appear in bold face.

TABLE 1. Morphological Characteristics of the Five Tropical Cucumber Varieties Cucumis sativus

\begin{tabular}{lllll}
\hline \multicolumn{1}{c|}{ Commercial name } & \multicolumn{1}{c|}{ Supplier } & \multicolumn{1}{c}{ Skin characteristics } & Length $\times$ diameter, cm \\
\hline Showy Green & Known-you seed Co., LTD (Taiwan) & Dark green with few white spines & $33 \times 7$ \\
Tropical & Technisem (France) & Dark green with smooth skin & $25 \times 6$ \\
F1 L-04 & Green.Co., LTD (Vietnam) & Medium green with white powder & $18 \times 4$ \\
Pointe Blanche & CIRAD Reunion (France) & Medium green with numerous white spines & $17 \times 6$ \\
Antilla & Technisem (France) & Medium green, light green ended & $15 \times 6$ \\
\hline
\end{tabular}

1) UMR Peuplements Vegetaux et Bioagresseurs en Milieu Tropical (CIRAD-Universite de La Reunion), 7 chemin de l'Irat, Ligne Paradis, 97410 Saint-Pierre, La Reunion, France, fax: +332 62499 293; 2) Laboratoire de Chimie des Substances Naturelles et des Sciences des Aliments, Universite de La Reunion, 15 Avenue Rene Cassin. CS 92 003, 97744 Saint-Denis cedex 9, La Reunion, France, fax: +332 62938 183, e-mail: anne.bialecki@univ-reunion.fr. Published in Khimiya Prirodnykh Soedinenii, No. 4, July-August, 2015, pp. 662-665. Original article submitted April 26, 2013. 
TABLE 2. Volatile Compounds Identified in Cucumber of Five Different Varieties by GC-MS (HS-SPME, \%) ${ }^{\mathrm{a}}$

\begin{tabular}{|c|c|c|c|c|c|c|}
\hline Compound & $\mathrm{LRI}^{\mathrm{b}}$ & Showy Green & Tropical & Pointe Blanche & F1 L-04 & Antilla \\
\hline \multicolumn{7}{|c|}{ Alkanes } \\
\hline$n$-Hexane & 607 & 1.5 & - & - & - & - \\
\hline$n$-Tetradecane & 1395 & 3.3 & 1.1 & - & - & 1.1 \\
\hline$n$-Pentadecane & 1493 & - & - & - & - & 1.9 \\
\hline$n$-Hexadecane & 1592 & - & - & - & - & 1.7 \\
\hline$n$-Heptadecane & 1692 & - & - & - & - & 1.3 \\
\hline Total, \% & & 4.8 & 1.1 & 0 & 0 & 6.0 \\
\hline \multicolumn{7}{|c|}{ Alkenes } \\
\hline Dodec-1-ene & 1188 & 0.9 & 0.4 & - & - & - \\
\hline Tridecene & 1287 & 2.7 & - & - & - & - \\
\hline Tetradec-1-ene & 1386 & 9.7 & 2.0 & 0.9 & - & 3.1 \\
\hline (E)-4,8-Dimethyl-1, 3,7-nonatriene & 1115 & - & 4.6 & - & - & \\
\hline Total, \% & & 13.3 & 7.0 & 0.9 & 0 & 3.1 \\
\hline \multicolumn{7}{|c|}{ Alcohols } \\
\hline Ethanol & 484 & 7.4 & 0.4 & 0.2 & 0.7 & 1.2 \\
\hline$n$-Hexanol & 865 & - & - & 4.0 & 2.2 & - \\
\hline 4-Methylpentanol & 864 & - & - & - & - & 1.9 \\
\hline$n$-Nonanol & 1167 & 1.4 & - & 24.7 & 20.7 & 30.7 \\
\hline (Z)-Non-6-en-1-ol & 1167 & - & 6.8 & - & - & - \\
\hline$n$-Decanol & 1288 & - & 0.5 & Tr. & - & - \\
\hline Total, $\%$ & & 8.8 & 7.7 & 28.9 & 23.6 & 33.8 \\
\hline \multicolumn{7}{|c|}{ Aldehydes } \\
\hline$n$-Hexanal & 803 & 2.0 & 0.3 & 1.8 & 2.7 & 1.4 \\
\hline Hex-2-enal (isomer $(2 E / 2 Z)$ not identified) & 852 & - & - & 0.9 & - & - \\
\hline$n$-Nonanal & 1102 & - & 2.0 & 11.4 & 24.7 & 15.5 \\
\hline$(E, Z)$-Nona-2,6-dienal & 1151 & - & - & Tr. & 1.1 & - \\
\hline (E)-Non-2-enal & 1157 & - & - & 1.1 & 2.9 & 1.0 \\
\hline$n$-Tridecanal & 1506 & 2.1 & 2.9 & Tr. & - & 1.6 \\
\hline$n$-Tetradecanal & 1606 & 10.0 & 5.3 & - & - & 4.4 \\
\hline$n$-Pentadecanal & 1708 & 33.1 & 19.8 & 0.9 & - & 17.3 \\
\hline Hexadeca-7,10-dienal* & 1884 & - & 5.7 & - & - & - \\
\hline Hexadeca-7,10,13-trienal* & 1890 & - & 3.6 & - & - & - \\
\hline$n$-Heptadecanal & 1911 & - & 0.4 & - & - & - \\
\hline Total, $\%$ & & 47.2 & 40.0 & 16.1 & 31.4 & 41.2 \\
\hline \multicolumn{7}{|c|}{ Esters } \\
\hline Ethyl acetate & 614 & - & 0.3 & - & - & - \\
\hline 3-Hexenyl acetate (isomer ( $3 E / 3 Z)$ not identified) & 1004 & - & - & 1.2 & - & - \\
\hline Hexyl acetate & 1011 & - & - & 40.6 & 0.4 & 1.7 \\
\hline Hexyl 2-methylbutanoate & 1237 & - & - & 0.5 & - & - \\
\hline Nonyl acetate & 1304 & - & - & 0.3 & - & - \\
\hline Total, $\%$ & & 0 & 0.3 & 42.6 & 0.4 & 1.7 \\
\hline \multicolumn{7}{|c|}{ Ethers } \\
\hline Ethyl ether & 512 & - & 0.9 & - & - & - \\
\hline Total, \% & & 0 & 0.9 & 0 & 0 & 0 \\
\hline \multicolumn{7}{|c|}{ Monoterpene hydrocarbons } \\
\hline Sabinene & 978 & - & - & 0.3 & - & - \\
\hline$\beta$-Pinene & 984 & - & - & 0.2 & - & - \\
\hline Limonene & 1032 & - & - & - & - & - \\
\hline (E)- $\beta$-Ocimene & 1047 & - & 1.9 & - & 1.9 & - \\
\hline Total, $\%$ & & 0 & 1.9 & 0.5 & & 0 \\
\hline \multicolumn{7}{|c|}{ Oxygenated monoterpenes } \\
\hline Linalool & 1098 & - & 1.7 & - & 0 & - \\
\hline Total, $\%$ & & 0 & 1.7 & 0 & 0 & 0 \\
\hline
\end{tabular}


TABLE 2. (continued)

\begin{tabular}{|c|c|c|c|c|c|c|}
\hline Compound & $\mathrm{LRI}^{\mathrm{b}}$ & Showy Green & Tropical & Pointe Blanche & F1 L-04 & Antilla \\
\hline \multicolumn{7}{|c|}{ Sesquiterpene hydrocarbons } \\
\hline$\beta$-Caryophyllene & 1430 & 6.6 & 12.6 & 2.9 & 26.2 & 1.6 \\
\hline trans- $\alpha$-Bergamotene & 1440 & - & 2.0 & 0.6 & - & - \\
\hline (E)- $\beta$-Farnesene & 1454 & - & 1.3 & 0.1 & - & - \\
\hline$\alpha$-Humulene & 1464 & 6.6 & 12.2 & 2.6 & 10.1 & 5.0 \\
\hline$\beta$-Bisabolene & 1510 & - & 0.7 & - & - & - \\
\hline$(Z)-\gamma$-Bisabolene & 1520 & 1.1 & 1.8 & 0.8 & - & - \\
\hline$\delta$-Cadinene & 1529 & - & 0.5 & - & - & - \\
\hline$(E)-\gamma$-Bisabolene & 1535 & - & 0.8 & 0.4 & - & - \\
\hline Total, \% & & 14.3 & 31.9 & 7.4 & 36.3 & 6.6 \\
\hline \multicolumn{7}{|c|}{ Oxygenated sesquiterpenes } \\
\hline Caryophyllene oxide & 1596 & - & 0.7 & - & - & - \\
\hline Humulene epoxide II & 1622 & - & 0.6 & - & - & - \\
\hline Total, \% & & 0 & 1.3 & 0 & 0 & 0 \\
\hline \multicolumn{7}{|c|}{ Miscellaneous compounds } \\
\hline 2-Pentylfuran & 992 & - & - & 1.4 & 3.5 & 1.2 \\
\hline Total, \% & & 0 & 0 & 1.4 & 3.5 & 1.2 \\
\hline Total identified, \% & & 88.4 & 93.8 & 97.8 & 98.3 & 93.6 \\
\hline
\end{tabular}

aLRI: Linear retention index calculated on nonpolar, SPB-5 column; ${ }^{b}$ relative percentage based on the peak area from the GC-MS analysis. Tr.: trace $(<0.1 \%) ;-$ absent.

The five cultivars were characterized by their high content of aldehydes $(47.2,40.0,16.1,31.4$, and 41.2\%, respectively, for "Showy Green," "Tropical," "F1 L-04," "Pointe Blanche," and "Antilla"), alcohols (8.8, 7.7, 28.9, 23.6, and 33.8\%), and sesquiterpene hydrocarbons $(14.3,32.6,7.4,36.3$, and 6.6\%). However, the headspace compositions of the five cultivars were not similar.

In the headspace of the "Showy Green" cultivar, 14 compounds were identified among which the major components were the two aldehydes pentadecanal (33.1\%) and tetradecanal (10.0\%).

Among the volatiles present in the vapor phase surrounding the fruits of "Tropical" cultivar, 29 were identified. The most abundant were pentadecanal (19.8\%) followed by the two sesquiterpene hydrocarbons caryophyllene (12.6\%) and $\alpha$-humulene (12.2\%).

Twenty-five volatile compounds were identified in the SPME extract from the "Pointe Blanche" cultivar. This cultivar can be distinguished from the other four cultivars by its very high level in hexyl acetate (40.6\%), absent or detected in insignificant amounts in "Showy Green," "Tropical," "F1 L-04," and "Antilla" samples. Other important constituents for the "Pointe Blanche" cultivar were the aliphatic alcohol $n$-nonanol (24.7\%) and the aldehyde $n$-nonanal (11.4\%).

$n$-Nonanol and $n$-nonanal were also among the main components detected by HS-SPME for the "F1-L04" cultivar. The percentages of these two compounds were indeed 20.7 and $24.7 \%$, respectively. Ten other constituents were identified for the "F1-L04" headspace. The sesquiterpene hydrocarbons caryophyllene (26.2\%) and $\alpha$-humulene (10.1\%) were the two other representative compounds.

For "Antilla," the unique pickling cultivar in this study, 17 volatile compounds were identified. Its headspace fraction was rich in $n$-nonanol (30.7\%), $n$-pentadecanal (17.3\%), and $n$-nonanal (11.4\%).

Volatile $\mathrm{C}_{6}$ to $\mathrm{C}_{9}$ aldehydes and alcohols are important contributors to the characteristic of flavours of fruits, vegetables and green leaves [8]. These shorter-chain volatiles are derived by oxidative cleavage and decarboxylation of linoleic and linolenic fatty acids [9] and are usually called "Green Leaf Volatiles" [10]. $n$-Hexanal, detected in the five cultivar profiles, has a strong, penetrating, fatty-green, grassy, unripe fruit odor. $n$-Nonanal, present in all cultivars except in "Showy Green," provides a very powerful and diffusive fatty-floral, waxy odor of moderate tenacity. $n$-Nonanol, mainly present in "Pointe Blanche," "F1 L-04," and "Antilla," is characterized by an oily-floral, rose-orange odor [11].

$(E, Z)$-Nona-2,6-dienal and (E)-non-2-enal, which have been considered as characteristic constituents of cucumber flavor [12], were detected in these five cultivars in very low amounts, probably due to the technique used to prepare the plant material. Indeed, in this work, volatiles are collected from pieces of cucumber instead of a blended preparation in the other papers [12]. In fact, $(E, Z)$-nona-2,6-dienal and $(E)$-non-2-enal are generated enzymatically in high amounts when the fruit is 
cut or mechanically ruptured in the presence of oxygen [1]. (E,Z)-Nona-2,6-dienal develops an extremely powerful and very diffusive green-vegetable odor, and only in dilution is it reminiscent (strikingly) of cucumber or violet leaf. At high concentrations, (E)-non-2-enal has an extremely powerful and very diffusive, penetrating, fatty-orrisy odor; in dilution, its scent is waxy, reminiscent of cucumber and melon [11].

Long-chain aldehydes such as pentadecanal have been detected in large amounts in three cultivars ("Showy Green," "Tropical," and "Antilla"). These kinds of compounds have been reported in other studies on cucumber [13]. The biogenesis of these saturated $\mathrm{C}_{15}, \mathrm{C}_{14}, \mathrm{C}_{13}$, and $\mathrm{C}_{12}$ aldehydes in cucumber is derived from palmitic acid [13].

Esters and terpenes are also important groups of compounds in cucumber odor. Esters are associated with "fruity" attributes of fruit flavor and typically increase to high levels late in the ripening process [14]. Straight-chain esters are thought to be synthetized from fatty acids via the lipoxygenase pathway [15], while branched chain esters are produced from the metabolism of branched amino acids such as isoleucine [16]. Hexyl acetate, recognized to have a sweet fruity berry- and pearlike odor, with slightly floral and green notes, is present in large amounts in the "Pointe Blanche" cultivar.

Volatile terpenes are derived directly from isoprenoid pyrophosphates or from the cleavage of carotenoids by carotenoid cleavage dioxygenases [17]. These compounds play an important role in plant-plant, plant-insect, and plant-pathogen interactions [18]. $\beta$-Caryophyllene is an important volatile sesquisterpene of plants that may serve as an allelochemical to influence the neighboring plant growth or as an indirect defense to attract natural herbivore enemies [19]. This compound has a woody-spicy, dry, and tenacious odor [11].

Source of Plant Materials. The five cucumber (Cucumis sativus) cultivars were grown in a greenhouse (CIRAD, Reunion) using seeds purchased from various suppliers (Table 1). Cucumber fruits were picked at the same stage of maturity (fully ripe) for volatile compounds analysis.

Collection of Volatile Compounds. The SPME holder for manual sampling and the fused silica fibers coated with divinylbenzene-carboxen-polydimethylsiloxane (DVB-CAR-PDMS, length $2 \mathrm{~cm}$, film thickness $50 / 30 \mu \mathrm{m}$ ) were both obtained from Supelco Co. (Bellefonte, PA, USA). The fibers were conditioned prior to use according to the supplier's prescriptions for $1 \mathrm{~h}$ at $270^{\circ} \mathrm{C}$.

Fresh and unpeeled fruits were cut into small cubes and placed in a $250 \mathrm{~mL}$ vial hermetically closed. The vial was maintained in a water bath during equilibration and extraction times and was partially submerged so that the pieces of fruits were in the water. After the equilibrating time, the SPME fiber was then manually inserted into the sample vial headspace. In order to determine the optimal conditions for extraction, the following parameters were evaluated: water bath temperature, sampling time, equilibration time, and sample volume. The selected parameters for optimal extractions were: water bath temperature: $37^{\circ} \mathrm{C}$; sampling time: $3 \mathrm{~h}$; equilibration time: $15 \mathrm{~min}$, sample volume: $100 \mathrm{~g}$. After extraction, the desorption of the analytes from the fiber coating was immediately made in the injection port of the $\mathrm{GC}$ at $250^{\circ} \mathrm{C}$ during 10 min. Reproducibility of SPME analysis of flavor compounds was evaluated by analyzing three lots of each cucumber.

GC-MS Analysis. This analysis was conducted on a Hewlett-Packard 6890 series-5972 GC-MS system equipped with a SPB-5 column $(60 \mathrm{~m} \times 0.32 \mathrm{~mm}$ i.d., film thickness $0.25 \mu \mathrm{m}$; Supelco Co., Bellefonte, PA, USA). The GC-MS instrument was operated at $70 \mathrm{eV}$ in the EI mode with a scan range of $\mathrm{m} / \mathrm{z}$ range 30-550. Helium was used as the carrier gas at a flow rate of $0.7 \mathrm{~mL} / \mathrm{min}$. The oven temperature was programmed from $60^{\circ} \mathrm{C}$ to $230^{\circ} \mathrm{C}$ at a rate of $4^{\circ} \mathrm{C} / \mathrm{min}$, held for $40 \mathrm{~min}$. The injector and the transfer line were both programmed to $250^{\circ} \mathrm{C}$. All analyses were done using the splitless injection mode.

Component identification was confirmed by comparison of mass spectral fragmentation patterns with those stored in the MS data bank (Wiley 7, NIST 2002) and those reported in the literature [20]. Linear retention indices (LRIs) on the polar and nonpolar columns, determined in relation to a homologous series of $n$-alkanes $\left(\mathrm{C}_{8}-\mathrm{C}_{26}\right)$, were additionally compared with published index data [21] and also with those of authentic standards.

\section{REFERENCES}

1. H. P. Fleming, W. Y. Cobb, J. L. Etchells, and T. A. Bell, J. Food Sci., 33 (6), 572 (1968).

2. $\quad$ C. Palma-Harris, R. F. McFeeters, and H. P. Fleming, J. Agric. Food Chem., 49 (9), 4203 (2001).

3. $\quad$ R. H. Buescher and R. W. Buescher, J. Food Sci., 66 (2), 357 (2001).

4. $\quad$ J. Song, L. H. Fan, and R. M. Beaudry, J. Agric. Food Chem., 46 (9), 3721 (1998).

5. A. Krumbein and D. Ulrich, in: Flavor Science. Recent Developments, Roy. Soc. Chem., 197, 289 (1996).

6. E. P. Jarvenpaa, Z. Y. Zhang, R. Huopalahti, and J. W. King, Z. Lebensm.-Unters. Forsch., 207 (1), 39 (1998). 
7. $\quad$ A. Steffen and J. Pawliszyn, J. Agric. Food Chem., 44 (8), 2187 (1996).

8. W. Schwab, R. Davidovich-Rikanati, and E. Lewinsohn, Plant J., 54 (4),712 (2008).

9. W. Grosch, Lipids, 6 (5), 351 (1971).

10. J. H. Visser, Annu. Rev. Entomol., 31, 121 (1986).

11. Flavor-Base 2007, Leffingwell \& Associates, Professional Edition, Canton, Georgia, USA, 2007.

12. D. A. Forss, E. A. Dunstone, E. H. Ramshaw, and W. Stark, J. Food Sci., 27 (1), 90 (1962).

13. T. Galliard and J. A. Matthew, Biochem. Biophys. Acta, 424, 26 (1976).

14. M. Bengtsson, A. C. Backman, I. Liblikas, M. I. Ramirez, A. K. Borg-Karlson, L. Ansebo, P. Anderson, J. Lofqvist, and P. Witzgall, J. Agric. Food Chem., 49 (8), 3736 (2001).

15. D. D. Rowan, J. M. Allen, S. Fielder, and B. M. Hunt, J. Agric. Food Chem., 47, 2553 (1999).

16. D. D. Rowan, H. P. Lane, J. M. Allen, S. Fielder, and B. M. Hunt, J. Agric. Food Chem., 44, 3276 (1996).

17. A. J. Simkin, S. H. Schwartz, M. Auldrigde, M. G. Taylor, and H. J. Klee, Plant J., 40, 882 (2004).

18. A. X. Cheng, Y. G. Lou, Y. B. Mao, S. Lu, L. J. Wang, and X. Y. Chen, J. Int. Plant Biol., 49, 179 (2007).

19. R. Wang, S. Peng, R. Zeng, L. W. Ding, and Z. Xu, Allelopathy J., 24 (1), 35 (2009).

20. R. P. Adams, Identification of Essential Oils by Gas Chromatography/Quadrupole Mass Spectroscopy, Allured Publishing Corp., Carol Stream, Illinois, 2004, 456 pp.

21. N. Kondjoyan and J. L. Berdague, A Compilation of Relative Retention Indices for the Analysis of Aromatic Compounds, $1^{\text {st }}$ Edn., Laboratoire Flaveur, France, 1996, 234 pp. 